\title{
Clostridium sp. 균주를 이용한 음식물스레기 산발효액로부터 부탄올 생산 Biobutanol production from Acid Fermented Solution of Food Waste using Clostridium sp.
}

\author{
이두근 $\cdot$ 윤정준 $^{\dagger}$ \\ Doo-Geun Lee $\cdot$ Jeong-Jun Yoon ${ }^{\dagger}$ \\ 한국생산기술연구원 지능형청정소재그룹 \\ Intelligent Sustainable Materials R\&D Group, Korea Institute of Industrial Technology
}

(Received April 5, 2018; Revised April 23, 2018; Accepted May 4, 2018)

\begin{abstract}
In Korea, more than five million tons of food waste is generated per year by restaurants and households. Owing to the increasing environmental issues, utilization of food waste has gained much attention for its potential in producing industrially important chemicals. Several researchers have investigated the use of acid fermentation processes for biogas production to effectively utilize food waste. Organic acids are one of the main components of the food waste acid fermentation process; these can be converted to alcohols, such as ethanol and butanol. Here, we produced butanol from organic acids using Clostridium beijerinckii, which is the most suitable among the five Clostridia strains tested. Organic acids at various concentrations were tested to optimize butanol production; $10.41 \mathrm{~g} / \mathrm{L}$ of butanol was produced from a mixed carbon source containing $10 \mathrm{~g} / \mathrm{L}$ butyric acid and $5 \mathrm{~g} / \mathrm{L}$ acetic acid. We also produced butanol using the Clostridium sp. and an acid fermented solution of food waste as the secondary carbon source. Up to $10.65 \mathrm{~g} / \mathrm{L}$ of butanol was produced using these mixed carbon sources, which contained $30 \mathrm{~g} / \mathrm{L}$ of glucose, $10.15 \mathrm{~g} / \mathrm{L}$ of butyric acid, and $5.01 \mathrm{~g} / \mathrm{L}$ of acetic acid.
\end{abstract}

Key Words : Butanol, Food Waste, Acid Fermentation, Clostridium

요약 : 매년 한국에서 음식물 쓰레기는 식당과 가정에서 500 만 톤 이상 배출된다. 환경 문제가 증대함에 따라 음식물 쓰레 기를 이용하여 산업적으로 중요한 화합물을 생산하는 연구가 주목받고 있다. 또한 많은 연구자들은 음식물 쓰레기로부터 바 이오가스를 생산하기 위해 이용하는 산발효 공정에 집중하고 있다. 특히, 음식물 쓰레기의 산발효 공정에는 에탄올과 부탄올 과 같은 알콜류로 전환 될 수 있는 유기산이 부산물로 다량 생산되며 이러한 유기산들은 활용되어야할 필요가 있다. 본 연구 에서는 Clostridium sp.에서 음식물 쓰레기 산발효액 내의 유기산을 2차 탄소원으로 이용하여 부탄올을 생산하고자 하였다. 5종의 Clostridia 균주 중에 Clostridium beijerinckii 가 가장 효과적으로 유기산을 이용하여 부탄올을 생산하였다. 효과적인 부 탄올 생산을 위해 유기산 조성을 최적화 하였으며 $10 \mathrm{~g} / \mathrm{L}$ 의 부티르산과 $5 \mathrm{~g} / \mathrm{L}$ 의 아세트산에서 $10.41 \mathrm{~g} / \mathrm{L}$ 의 부탄올을 생산하 였다. 최적 유기산 조성을 바탕으로 구성된 음식물 쓰레기 산발효액 유래의 $10.15 \mathrm{~g} / \mathrm{L}$ 의 부티르산, $5.01 \mathrm{~g} / \mathrm{L}$ 의 아세트산과 30 $\mathrm{g} / \mathrm{L}$ 의 글루코스로 이루어진 혼합 탄소원을 이용하여 $10.65 \mathrm{~g} / \mathrm{L}$ 의 부탄올을 생산하였다.

주제어 : 부탄올, 음식물쓰레기, 산발효, 클로스트리디움

\section{1. 서 론}

현재의 바이오에탄올(Bioethanol) 중심의 차세대바이오연 료 체계는 많은 문제점을 가진다. 바이오에탄올은 에너지 밀도가 낮아 연비가 낮으며 친수성이 강하고 부식성이 높 아 기존의 인프라를 사용하지 못하기 때문에 새로운 인프 라의 구축이 필요하다는 단점이 있다. ${ }^{1)}$ 부탄올(Butanol)은 에탄올(Ethanol)에 비해 에너지 밀도가 높아 휘발유와 혼합 하여 사용 시 연비손실이 적으며, 물에 대한 용해도와 부식 성이 낮아 휘발유의 유통 인프라를 변경없이 사용할 수 있 으며 기존 차량의 개조 없이 고농도로 사용할 수 있다는 장 점을 가진다. 또한 바이오부탄올은 바이오에탄올보다 유사 하거나 더 높은 온실가스 저감효과가 있어 환경 측면에서 도 우수하다. ${ }^{2}$ 이러한 이유 때문에 물성이 뛰어난 부탄올이 에탄올을 대체할 바이오연료로 주목받고 있다.

미생물을 이용한 부탄올 생산은 100 년 이상 연구되어 왔으
며 1920년부터 1980년까지 많은 나라에서 바이오부탄올을 상 업적으로 생산하였다. 전통적으로 바이오부탄올은 Clostridium $\mathrm{sp}$.를 이용하여 다양한 sugar로부터 생산되었다. ${ }^{3)}$ Clostridium $\mathrm{sp}$.는 혐기 조건하에서 탄수화물을 바이오부탄올로 전환한 다. 이 때 사용되는 탄수화물은 사탕수수유래당 및 감자 유 래 전분 등이며 최종 부탄올 농도는 $10 \mathrm{~g} / \mathrm{L}$ 였다. ${ }^{4)}$ 대부분의 Clostridium sp.은 부탄올을 포함하여 유기용매(Organic solvent) 화합물의 농도가 $20 \mathrm{~g} / \mathrm{L}$ 를 상회하면 주요한 세포 대사 활동 이 정지한다고 알려져 있다. ${ }^{5)}$ 이를 해결하기 위해 Gas-stripping, Liquid-liquid extraction, Perstraction, Pervaporation와 같은 공정들을 발효 공정에 연계하여 부탄올의 연속제거를 통해 생산량을 증대하는 방법이 연구되어 왔다. ${ }^{6}$

바이오부탄올의 생산에 있어 원료비가 생산원가에 차지하 는 비중이 $70 \%$ 이상이기 때문에 옥수수 전분, 당밀과 같은 원료가격의 상승으로 인해 많은 바이오부탄올 상업공장들 은 가동을 중단하였다. 현재 대부분의 부탄올은 석유화학기 
반의 공정을 통하여 생산이 되고 있으나 원유 가격의 상승 과 에너지 안보 불안정에 따른 문제들이 대두됨에 따라 저 렴한 바이오매스를 이용한 바이오연료 생산에 대한 연구가 진행되고 있다. ${ }^{78)}$

환경오염의 주범으로 지탄받던 음식물쓰레기를 자원화하 는 기술의 연구가 전 세계적으로 진행되고 있으며 그 중 음 식물쓰레기의 혐기성소화(Anaerobic digestion)에 의한 바이 오가스(Biogas) 생산이 온실가스 감축에 의한 환경적 이익 뿐만 아니라 경제성 확보 역시 기대할 수 있어 주목받고 있 다. 그리고 바이오가스는 자국의 폐기자원을 활용하여 생 성될 수 있다는 장점과 기존의 천연가스 자동차 및 가스 인 프라를 사용할 수 있다는 점에서 공급체계의 이점이 있다. ${ }^{9)}$

음식물쓰레기 이용한 바이오가스 생산 위한 혐기성소화 공정 시 다량의 유기산(Organic acid)이 부산물로 생성된다. ${ }^{10)}$ 1 톤의 음식물쓰레기로부터 약 $110 \mathrm{~m}^{3}$ 의 바이오가스가 생 산될 수 있으며 또한 이 때 생성된 유기산을 이용하여 생산 될 수 있는 알콜은 약 $20 \mathrm{~kg}$ 으로 예상된다. ${ }^{11)}$ 특히, 유기산 중 대부분은 부티르산(Butyric acid)이며 이를 활용해야 할 필요가 있다. Clostridium sp.에서는 부티르산을 이용하여 부 탄올로 전환이 가능한 대사경로를 가지고 있다. 소량의 부 티르산은 부탄올 생합성 경로 유전자들을 유도(Induction)하 여 산생성단계(Acidogenesis)에서 용매생성단계(Solventogenesis)로의 전환을 촉진한다고 알려져 있다. ${ }^{12)}$ 하지만 부티 르산은 세포 독성(Cell toxicity)을 유발하기 때문에 과량 첨 가 시 세포 생장(Cell growth) 저해를 유발한다 알려져 있어 부탄올 생산 연구 시 소량만 사용되어 왔으며 주탄소원으로 의 이용은 연구되지 않았다. ${ }^{13)}$

본 연구에서는 주 탄소원으로 음식물쓰레기 산발효액 유 래의 유기산을 이용하여 부탄올을 생산하였다. 유기산을 효 과적으로 이용하여 부탄올을 생산할 수 있는 Clostridium sp. 균주를 선정하였으며 부탄올의 효과적인 생산을 위해 최적 유기산 조성을 조사하였다. 또한 최적 유기산 조성을 바탕 으로 음식물쓰레기 산발효액을 구성하고 배양하여 부탄올을 효과적으로 생산하였다.

\section{2. 실험재료 및 방법}

\section{1. 미생물}

본 연구에 사용된 균주는 KCTC (Korean Collection for Type Cultures)와 ATCC (American Type Culture Collection) 에서 구입하였으며 C. acetobutylicum KCTC 1724, C. beijerinckii KCTC 2203, C. carboxidivorans ATCC BAA624, C. pasteurianum KCTC 1674, and C. tyrobutyricum KCTC 5387 을 사용하였다. 균주는 포자(Spore) 상태로 1 milliliter $(\mathrm{mL})$ 의 Potato glucose $(\mathrm{PG})$ medium에서 보관되었다. 휴면상태의 포자의 활성화를 위해 $1 \mathrm{~mL}$ 의 포자를 $9 \mathrm{~mL}$ 의 PG medium 에 부유하고 이 용액을 $100^{\circ} \mathrm{C}$ 의 항온수조에서 1 분간 가열 하였으며 $30^{\circ} \mathrm{C}$ 에서 24 시간 동안 전배양하였다.

\section{2. 배양 배지}

본 연구에서 전 배양을 위해 Reinforced Clostridial Medium (RCM)이 사용되었으며 본 배양을 위해서 P2 배지(P2 medium) 가 사용되었다. $\mathrm{P} 2$ 배지의 조성은 $3 \mathrm{~g} / \mathrm{L}$ yeast extract, $1 \mathrm{~g} / \mathrm{L}$ tryptone, $0.2 \mathrm{~g} / \mathrm{L} \mathrm{MgSO}_{4}, 2 \mathrm{~g} / \mathrm{L} \mathrm{KH}_{2} \mathrm{PO}_{4}, 2 \mathrm{~g} / \mathrm{L} \mathrm{K}_{2} \mathrm{HPO}_{4}, 0.2$ $\mathrm{g} / \mathrm{L} \mathrm{MgSO}_{4}, 0.01 \mathrm{~g} / \mathrm{L} \mathrm{MnSO} \mathrm{H}_{4}, 0.01 \mathrm{~g} / \mathrm{L} \mathrm{FeSO}_{4} \cdot 7 \mathrm{H}_{2} \mathrm{O}, 0.01 \mathrm{~g} / \mathrm{L}$ $\mathrm{NaCl}$ 으로 구성하였다. ${ }^{14)}$ 액체배지는 $121{ }^{\circ} \mathrm{C}$ 에서 15 분 동안 고압멸균 되었다. 배양(Cultivation)은 $10 \mathrm{~mL}$ 의 P2 배지가 함유된 $50 \mathrm{~mL}$ 의 주사약병(Serum-bottle)에서 수행하였다. 균 주를 $5 \%(\mathrm{v} / \mathrm{v})$ 로 접종한 주사약병은 $37^{\circ} \mathrm{C}, 200 \mathrm{rpm}$ 에서 배 양되었으며 배지의 초기 $\mathrm{pH}$ 를 $6 \mathrm{~N}$ 의 $\mathrm{NaOH}$ 를 이용하여 6.5 로 조정하였다. ${ }^{15)}$

\section{3. 부탄올 및 유기산 분석}

배양액 $1 \mathrm{~mL}$ 을 20 분간 원심 분리한 후 상층액만을 취해 정량 분석하였다. 부탄올, 부티르산, 아세트산, 글루코스의 분석 시스템은 Liquid chromatography system with refractive index detector (1260 LC system, Agilent, USA)을 이용 하였으며 분석칼럼은 Aminex HPX-87H $(300 \times 7.8 \mathrm{~mm}$, Biorad, USA)을 사용하였다. 이동상은 $5 \mathrm{mM}$ 황산 $\left(\mathrm{H}_{2} \mathrm{SO}_{4}\right)$ 을 사용하였으며 칼럼 온도는 $60^{\circ} \mathrm{C}$, 유속(Flow rate)은 0.6 $\mathrm{mL} / \mathrm{min}$ 이다. ${ }^{16)}$

\section{4. 음식물쓰레기 산발효액의 제조}

한국생산기술연구원 내 식당에서 배출한 음식물쓰레기에 $10 \%(\mathrm{v} / \mathrm{v})$ 의 수돗물을 첨가하여 혐기 산발효(Anaerobic acid fermentation) 수행하였다. 음식물쓰레기는 플라스틱, 실, 씨 앗, 비닐, 뼈와 같이 기질로서 부적합한 물질들을 제거한 후 분쇄기(Waring laboratory, USA)를 이용하여 $2.0 \mathrm{~mm}$ 이하 로 하여 사용하였다. 보조기질로써 대전광역시 시설관리공 단의 하수처리장에서 발생하는 생 슬러지와 잉여슬러지를 $1: 1$ (부피비)로 혼합한 슬러지를 이용하였으며 $61.7 \mathrm{~L}$ 의 반 응기에 음식물쓰레기와 슬러지를 첨가하여 회분식 산발효 수행하였다. 산발효 공정의 $\mathrm{pH}$ 는 $10 \mathrm{~N} \mathrm{KOH}$ 이용하여 $\mathrm{pH}$ 6 로 유지되었으며 $37^{\circ} \mathrm{C}, 120 \mathrm{rpm}$ 으로 운전되었다.

\section{5. 음식물쓰레기 산발효액의 부유물질 제거}

음식물쓰레기 산발효액의 부유물질을 제거하기 위해 고 분자 응집제(Macromolecule Flocculant)를 첨가하였다. 고분 자 응집제는 C820-EMB (SNF Korea, Republic of Korea)를 사용하였으며 첨가 농도는 $100 \mathrm{ppm}$ 이다. 산발효액에 응집 제 첨가 후 30 분간 $100 \mathrm{rpm}$ 으로 교반하고 $3000 \mathrm{rpm}$ 에서 20 분간 원심분리 하였다.

\section{3. 결과 및 고찰}

\subsection{Clostridium sp. 에서 유기산 이용 부탄올 생산}


Clostridium sp.는 부티르산을 부탄올로 전환할 수 있는 대사경로를 가지고 있다(Fig. 1). 이 대사경로를 이용하여 부탄올을 생산하고자 하였으며 우선적으로 유기산을 이용 하여 부탄올을 효과적으로 생산하는 균주를 선별하기 위해 C. acetobutylicum, C. beijerinckii, C. carboxidivorans, C. pasteurianum, C. tyrobutyricum 를 이용하여 실험하였다. 10 $\mathrm{mL}$ 의 P2 배지에 산발효액의 주요 유기산인 부티르산과 아 세트산을 각각 $10.05 \mathrm{~g} / \mathrm{L}, 5.23 \mathrm{~g} / \mathrm{L}$ 첨가하였으며 또한 30 $\mathrm{g} / \mathrm{L}$ 의 글루코스(Glucose)를 첨가하여 $37^{\circ} \mathrm{C}, 200 \mathrm{rpm}$ 에서 3 일간 진탕배양(Shaking incubation)하였다.

Clostridium sp. 균주에 따른 부탄올의 생산을 Table 1에 나타내었다. C. beijerinckii에서 가장 많은 $10.92 \mathrm{~g} / \mathrm{L}$ 의 부 탄올이 생산되었으며 기질인 부티르산은 $6.65 \mathrm{~g} / \mathrm{L}$ 그리고 글루코스는 $29.81 \mathrm{~g} / \mathrm{L}$ 소모되었다. C. acetobutyricum, C. carboxydivorans, C. pasteurianum, C.tyrobutyricum 에서 각각 $1.26,2.50,2.25,0 \mathrm{~g} / \mathrm{L}$ 의 부탄올을 생산하였으며, 특히 $C$. beijerinckii와 다르게 기질인 부티르산을 전혀 소모하지 못 하였다. Clostridium sp.는 아세트산을 탄소원으로 이용하는 대사경로가 없기 때문에 배양 시 소모하지 못하고 증가함이 확인되었다. 아세트산을 탄소원으로 이용하기 위해서 관계된 효소인 Butyrate-acetoacetate CoA-transferase를 과발현 하여 아세톤(Acetone), 부탄올과 같은 유기용매 화합물의 생산에 이 용 가능케 함이 보고되었다. ${ }^{17)}$ 이 결과를 통해 C. beijerinckii 가 부티르산을 가장 효과적으로 이용하여 부탄올을 생산하 는 것으로 판단된다.

\section{2. 효과적인 부탄올 생산위한 유기산 조성 최적화}

부탄올 생산에서 기질로 사용될 수 있는 유기산은 세포독 성이 있어 과량 첨가 시 세포 생장 저해를 유발할 수 있다. ${ }^{18}$ 따라서 효과적인 부탄올 생산을 위해 최적 유기산 농도로

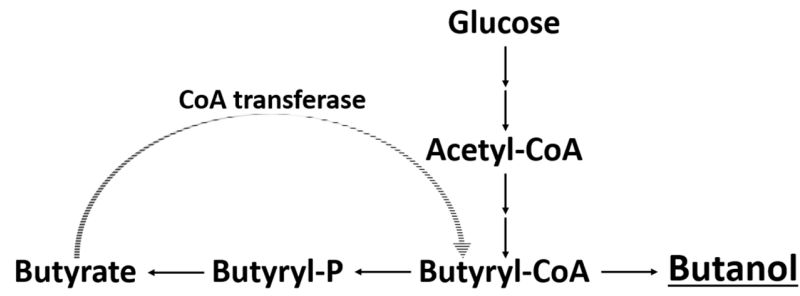

Fig. 1. Pathway for conversion of butyrate to butanol.

Table 1. Butanol production using organic acid by Clostridium sp

\begin{tabular}{lcccc}
\hline \multicolumn{1}{c}{ Strain } & $\begin{array}{c}\text { Butanol } \\
(\mathrm{g} / \mathrm{L})\end{array}$ & $\begin{array}{c}\text { Con- } \\
\text { sumed } \\
\text { butyric } \\
\text { acid (g/L) }\end{array}$ & $\begin{array}{c}\text { Con- } \\
\text { sumed } \\
\text { glucose } \\
(\mathrm{g} / \mathrm{L})\end{array}$ & $\begin{array}{c}\text { Change } \\
\text { amount of } \\
\text { acetic acid } \\
(\mathrm{g} / \mathrm{L})\end{array}$ \\
\hline \hline C. acetobutylicum & $1.26 \pm 0.32$ & 0 & $18.83 \pm 0.79$ & $+1.02 \pm 0.20$ \\
C. beijerinckil & $10.92 \pm 0.39$ & -6.65 & $29.81 \pm 0.98$ & $+2.82 \pm 0.04$ \\
C. carboxidivorans & $2.50 \pm 0.03$ & 0 & $17.51 \pm 2.67$ & $+4.18 \pm 0.16$ \\
C. pasteurianum & $2.25 \pm 0.06$ & 0 & $18.80 \pm 0.00$ & $+4.24 \pm 0.01$ \\
C. tyrobutyricum & 0 & 0 & $19.81 \pm 2.11$ & $+1.95 \pm 0.08$ \\
\hline
\end{tabular}

Table 2. Optimization of organic acids composition for butanol production

\begin{tabular}{ccccc}
\hline Butyric acid (g/L) & 0 & 5 & 10 & 15 \\
\hline \hline Acetic acid (g/L) & & & & \\
\hline 0 & 0.15 & 7.21 & 9.97 & 10.01 \\
5 & 4.45 & 8.12 & 10.41 & 9.84 \\
8 & 4.33 & 7.57 & 8.73 & 2.21 \\
15 & 4.02 & 7.80 & 4.58 & 0 \\
\hline
\end{tabular}

조성된 음식물쓰레기 산발효액이 필요하다. 최적 유기산 조 성을 찾기 위해 $0,5,10,15 \mathrm{~g} / \mathrm{L}$ 의 시약급 부티르산과 0,5 , $10,15 \mathrm{~g} / \mathrm{L}$ 의 시약급 아세트산을 각각 조합하고 P2 medium 에 기질로 첨가하여 배양 수행하였다. 균주는 C. beijerinckii 를 사용하였으며 다양한 농도의 유기산들을 첨가하고 초기 $\mathrm{pH}$ 가 6.5 로 조정된 $10 \mathrm{~mL}$ 의 $\mathrm{P} 2$ medium에서 $37^{\circ} \mathrm{C}, 72$ 시간 동안 진탕배양을 수행하였다.

유기산 조성에 따른 부탄올 생산을 Table 2에 나타내었다. 플라스크 배양(Flask cultivation)에서 유기산이 첨가되지 않 았을 때 글루코스만 기질로 첨가되었을 때는 부탄올이 0.15 $\mathrm{g} / \mathrm{L}$ 생산되었다. $0,5,10,15 \mathrm{~g} / \mathrm{L}$ 의 아세트산 첨가 실험에 서 아세트산 첨가 시 부탄올의 생산이 증가하나 약 $4 \mathrm{~g} / \mathrm{L}$ 으 로 제한되었다. 이는 C. beijerinckiii 가 아세트산을 탄소원으 로 직접 이용하지 못하여 제한되었으며 아세트산이 부탄올 생합성 유전자를 유도하기 때문에 부탄올 생산량이 증가되 었음으로 판단된다. ${ }^{19)}$ 부티르산이 $0,5,10,15 \mathrm{~g} / \mathrm{L}$ 첨가된 실험에서 기질인 부티르산의 첨가량이 증가할수록 부탄올 의 생산량이 증가하나 약 $10 \mathrm{~g} / \mathrm{L}$ 이 최대임을 알 수 있다 이 는 $\mathrm{Lu}$ 의 연구결과와도 유사하다. ${ }^{20)}$ 이러한 부탄올 생산량 제 한은 유기용매 화합물의 농도가 $20 \mathrm{~g} / \mathrm{L}$ 를 상회하면 주요한 세포 대사 활동이 정지하기 때문이다. 총 유기산 량이 $20 \mathrm{~g} / \mathrm{L}$ 가 초과하게 되면 부탄올의 생산량이 급격히 저하되는 것으 로 보이며 유기산 총량이 $30 \mathrm{~g} / \mathrm{L}$ 일 때 부탄올이 생산되지 않음을 알 수 있다. 이는 기질 저해(Substrate inhibition)로 유 발된 대사활동 저해로 인한 결과라고 사료된다. $10 \mathrm{~g} / \mathrm{L}$ 의 부티르산과 $5 \mathrm{~g} / \mathrm{L}$ 의 아세트산이 첨가 되었을 때 가장 많은 $10.41 \mathrm{~g} / \mathrm{L}$ 의 부티르산이 생산되었다. 이 유기산 조합은 음 식물쓰레기 산발효액 이용 배양 실험에 반영되었다.

\section{3. 음식물쓰레기 산발효액의 제조}

음식물쓰레기를 이용하여 수소와 같은 바이오가스를 생 산하기 위해 산발효 공정을 수행하였다. 이 때 부산물로 부 티르산, 아세트산 같은 유기산이 생산된다. 음식물쓰레기의 탄수화물은 $123.3 \mathrm{~g} \mathrm{COD} / \mathrm{L}$ 이며 유기산은 $1.4 \mathrm{~g} \mathrm{COD} / \mathrm{L}$ 이다. 파쇄된 음식물쓰레기는 초기 기질의 농도를 $60 \mathrm{~g} \mathrm{COD} / \mathrm{L}$ 가 되도록 증류수와 희석한 후 $61.7 \mathrm{~L}$ 반응기에 공급하였 다. $10 \mathrm{~N} \mathrm{HCl}$ 을 이용하여 기질의 $\mathrm{pH}$ 를 2로 낮추고 약 16 시간 동안 상온에서 교반하였다. 전처리가 끝난 후 음식물 쓰레기 용량의 $10 \%(\mathrm{v} / \mathrm{v})$ 의 하수슬러지를 반응기에 공급한 후 $10 \mathrm{~N} \mathrm{KOH}$ 를 사용하여 초기 $\mathrm{pH} 8.0$ 으로 조절하였고, 반 
Table 3. Organic acid composition of acid fermented solution of food waste

\begin{tabular}{ccccc}
\hline & $\begin{array}{c}\text { Butyric } \\
\text { acid }(\mathrm{g} / \mathrm{L})\end{array}$ & $\begin{array}{c}\text { Acetic acid } \\
(\mathrm{g} / \mathrm{L})\end{array}$ & $\begin{array}{c}\text { Lactic acid } \\
(\mathrm{g} / \mathrm{L})\end{array}$ & $\begin{array}{c}\text { Propionic acid } \\
(\mathrm{g} / \mathrm{L})\end{array}$ \\
\hline \hline $\begin{array}{c}\text { Acid fermented } \\
\text { solution of food } \\
\text { waste }\end{array}$ & 12.69 & 6.22 & 0.17 & 1.24 \\
\hline
\end{tabular}

응기 내부는 질소 치환하여 혐기상태로 산발효를 시작하였 다. 산발효가 진행되는 동안 $10 \mathrm{~N} \mathrm{KOH}$ 를 이용하여 $\mathrm{pH}$ 6으 로 유지하였다. 전처리 기간에는 $60 \mathrm{rpm}$, 산발효 기간에는 $120 \mathrm{rpm}$ 으로 교반하였으며 $37^{\circ} \mathrm{C}$ 에서 운전하였다. 공정에서 부산물로 생성된 산발효액 내의 유기산의 조성은 Table 3과 같으며 산발효액을 회수하여 부탄올 생산에 사용하였다.

\section{4. 음식물쓰레기 산발효액의 부유물질 제거 유무에 따른 부탄올 생산}

음식물쓰레기 산발효액에는 미생물 생장에 방해가 될 수 있는 많은 양의 부유물질(Suspended solid)이 다량 함유되어 있다. $100 \mathrm{ppm}$ 의 고분자 응집제(Macromolecule flocculant) 를 처리하여 산발효액 내의 부유물질을 제거하였고 부유물 질의 유무에 따른 부탄올 생산을 확인하였다. 배양에 사용 된 균주는 C. beijerinckii이며 배양배지는 산발효액을 기반 으로 제조하였으며 탄소원의 조성은 $7.80 \mathrm{~g} / \mathrm{L}$ 의 부티르산, $3.57 \mathrm{~g} / \mathrm{L}$ 의 아세트산, $30 \mathrm{~g} / \mathrm{L}$ 글루코스이다. 배양 결과는 Table 4에 나타내었다. 고분자 응집제를 첨가한 배양액에서 $6.45 \mathrm{~g} / \mathrm{L}$ 의 부탄올이 생산되었으며 기질인 부티르산이 5.75 $\mathrm{g} / \mathrm{L}$ 소모되었으며 $24.16 \mathrm{~g} / \mathrm{L}$ 의 글루코스가 소모되었다. 고분 자 응집제를 첨가하지 않은 배양액에서 $7.03 \mathrm{~g} / \mathrm{L}$ 의 부탄올 이 생산되었으며 부티르산이 $6.02 \mathrm{~g} / \mathrm{L}$ 그리고 $23.29 \mathrm{~g} / \mathrm{L}$ 의 글루코스가 소모되었다. 음식물쓰레기 산발효액의 부유물질 제거 유무에 따른 부탄올 생산량과 부티르산 소모량은 차 이 없음으로 사료되며 따라서 음식물쓰레기 내의 부유물질 은 Clostridium sp.를 이용한 부탄올 생산에서 저해를 유발 하지 않는 것으로 판단된다.

\section{5. 음식물쓰레기 산발효액 이용 부탄올 생산}

부탄올 생산에 기질로 사용된 음식물쓰레기 산발효액의

Table 4. Butanol production using acid fermented solution of food waste with macromolecule flocculant

\begin{tabular}{|c|c|c|c|}
\hline $\begin{array}{c}\text { Butanol } \\
\text { (g/L) }\end{array}$ & $\begin{array}{c}\text { Consumed } \\
\text { butyric acid } \\
(\mathrm{g} / \mathrm{L})\end{array}$ & $\begin{array}{l}\text { Consumed } \\
\text { glucose } \\
\text { (g/L) }\end{array}$ & $\begin{array}{l}\text { Change } \\
\text { amount of } \\
\text { acetic acid } \\
(\mathrm{g} / \mathrm{L})\end{array}$ \\
\hline
\end{tabular}

Added

macromolecule $\quad 6.45 \pm 0.06 \quad 4.85 \pm 0.06 \quad 24.16 \pm 0.13 \quad 2.17 \pm 0.04$ flocculant

Absence

macromolecule $7.03 \pm 0.12 \quad 6.02 \pm 0.01 \quad 23.29 \pm 0.05 \quad 1.88 \pm 0.03$ flocculant
조성은 Table 4에 나타내었다. 총 유기산의 농도가 약 20 $\mathrm{g} / \mathrm{L}$ 로 높기 때문에 앞서 조사된 최적 유기산 조성에 맞추 어 P2 배지에 첨가하였다. 산발효액 기반으로 조성된 배양 배지의 유기산은 $10.15 \mathrm{~g} / \mathrm{L}$ 의 부티르산, $5.01 \mathrm{~g} / \mathrm{L}$ 의 아세트 산, $0.12 \mathrm{~g} / \mathrm{L}$ 의 락트산(Lactic acid), $1.01 \mathrm{~g} / \mathrm{L}$ 의 프로피온산 (Propionic acid)이다. 또한 음식물쓰레기 산발효액과 동량 의 시약급 유기산을 P2 배지에 첨가 후 배양하여 음식물쓰 레기 산발효액의 부탄올 생산 원료로의 가능성을 확인하였 다. 균주는 C. beijerinckii이며 초기 $\mathrm{pH}$ 가 6.5 로 조정된 $10 \mathrm{~mL}$ 의 $\mathrm{P} 2$ 배지에서 $37^{\circ} \mathrm{C}, 96$ 시간 동안 진탕 배양하였다.

배양 결과는 Fig.2에 나타내었다. 시약급 유기산 이용 시 $9.74 \mathrm{~g} / \mathrm{L}$ 의 Butanol이 72시간에서 생산되었으며 이 때 첨가 된 $10.23 \mathrm{~g} / \mathrm{L}$ 의 부티르산이 전량 소모되었다. 이 때 세포 생 장(Cell growth)은 $\mathrm{OD}_{600 \mathrm{~nm}} 2.62$ 이었다. 음식물쓰레기 산발 효액을 탄소원으로 이용 시 $10.06 \mathrm{~g} / \mathrm{L}$ 의 Butanol이 배양 72 시간에서 생산되었으며 이 때 $7.54 \mathrm{~g} / \mathrm{L}$ 의 부티르산이 소모 되었으며 시약급 유기산이용 배양시보다 $2.87 \mathrm{~g} / \mathrm{L}$ 가량 낮 은 소모량이다. 또한, 세포 생장은 $\mathrm{OD}_{600 \mathrm{~nm}} 2.13$ 이었으며 시 약급 유기산이용 배양 시 보다 $\mathrm{OD}_{600 \mathrm{~nm}} 0.5$ 낮았으며 이러한 세포 생장 저해와 부티르산의 소모저해는 산발효액의 저해 제로 인해 야기된 결과라 판단된다. 부탄올의 생산성(Productivity)은 시약급 유기산 이용 시와 음식물쓰레기 산발효 액 이용 시 각각 $0.14 \mathrm{~g} / \mathrm{L} / \mathrm{hour}, 0.13 \mathrm{~g} / \mathrm{L} / \mathrm{hour}$ 으로 큰 차이
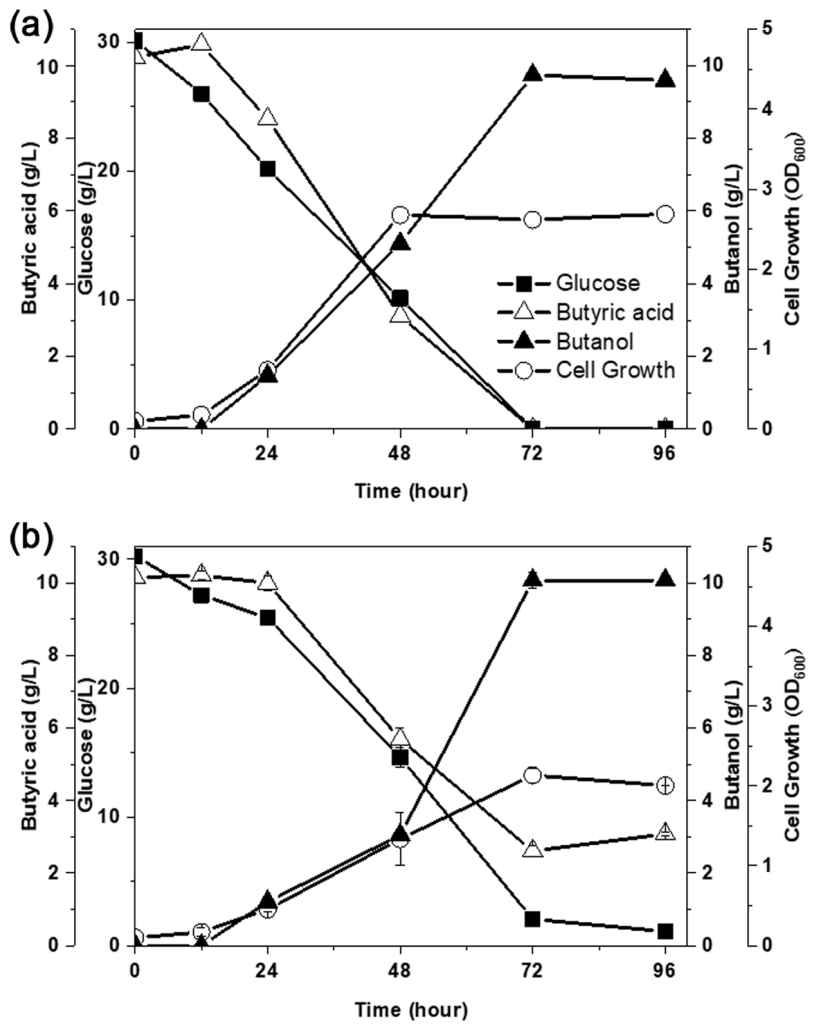

Fig. 2. Butanol production using organic acid by $\mathrm{C}$. beijerinckii (a) profile of butanol production using pure organic acid, (b) profile of butanol production using organic acid derived from acid fermented solution of food waste. 
Table 5. Butanol production according to dilution ratio of acid fermented solution of food waste

\begin{tabular}{cccc}
\hline $\begin{array}{c}\text { Dilution ratio } \\
(\mathrm{v}: \mathrm{v})\end{array}$ & $\begin{array}{c}\text { Butanol } \\
\text { (g/L) }\end{array}$ & $\begin{array}{c}\text { Consumed butyric } \\
\text { acid }(\mathrm{g} / \mathrm{L})\end{array}$ & $\begin{array}{c}\text { Cell growth } \\
\left(\mathrm{OD}_{600}\right)\end{array}$ \\
\hline \hline $1: 0$ & 10.02 & 7.11 & 1.98 \\
$1: 1$ & 10.17 & 8.47 & 2.61 \\
$1: 3$ & 9.88 & 9.51 & 2.73 \\
$1: 9$ & 10.15 & 10.16 & 2.88 \\
\hline
\end{tabular}

없음으로 사료된다. 음식물쓰레기 산발효 공정에서 생성되 는 유기산은 부탄올로의 생산에 효과적으로 이용될 수 있음 으로 판단된다.

산발효액내의 저해제의 부탄올 생산에 대한 영향을 분석 하기 위하여 산발효액에 $1: 0,1: 1,1: 3,1: 9$ (산발효액 부 피 : 증류수 부피)로 증류수를 첨가하여 산발효액 농도를 다 르게 하여 배양하였다. 모든 배양액에 시약급 유기산을 첨 가하여 부티르산과 아세트산 농도가 각각 $10 \mathrm{~g} / \mathrm{L}, 5 \mathrm{~g} / \mathrm{L}$ 가 되도록 제조하였다. 배양결과는 Table 5에 나타내었다. 부탄 올의 생산량은 $1: 0 \sim 1: 9$ 로 희석된 산발효액 이용 시 모두 약 $10 \mathrm{~g} / \mathrm{L}$ 로 유사하였으나 부티르산의 소모량과 세포 생장 에서 산발효액 희석배수가 높아질수록 부티르산의 소모량 과 세포 생장이 상승하였다. 이는 산발효액내의 저해제의 농 도가 낮아져 부티르산 소모 저해와 세포 생장 저해가 해소 되었음으로 인한 결과라 사료된다. 산발효액 이용 부탄올 생 산 시 부티르산의 이용과 세포 생장 증대 위해 저해제 제거 의 추가적인 고찰이 필요하다.

\section{4. 결 론}

본 연구에서는 음식물쓰레기의 산발효 공정 중 생성되는 유기산을 이용하여 부탄올을 생산하기 위해 기초실험을 수 행하였다. 5종의 Clostridium sp. 균주 중 유기산을 이용하여 부탄올 생산량이 가장 많은 균주를 선별하였고 효과적인 부 탄올 생산 위해 최적 유기산 조성을 조사하였다. 미생물 생 장에 저해될 수 있는 부유물질을 제거하여 부탄올 생산량 변 화를 확인하였고 음식물쓰레기 산발효액을 이용한 부탄올 생산 실험을 통해 부탄올 생산의 원료로의 이용 가능성을 확인하였다.

1) 부티르산, 아세트산, 글루코스로 이루어진 혼합 탄소원 에서 5종의 Clostridium sp. 중 C. beijerinckii 가 가장 효과적 으로 부탄올을 생산하였다.

2) 부탄올 생산 증대 위해 최적의 유기산 조성을 조사하 였으며 $10 \mathrm{~g} / \mathrm{L}$ 의 부티르산과 $5 \mathrm{~g} / \mathrm{L}$ 의 아세트산이 첨가되었 을 때 $10.41 \mathrm{~g} / \mathrm{L}$ 의 부탄올이 생산되었다.

3) 세포 생장에 저해가 될 수 있는 산발효액 내의 부유물 질을 제거하기 위해 고분자 응집제를 첨가하였다. 부유물질 제거 유무에 따라 부탄올 생산량의 차이는 없었으며 부유물 질이 부탄올 생산에 저해를 유발하지 않는 것으로 사료된다.
4) 음식물쓰레기 산발효액을 이용하여 $10.06 \mathrm{~g} / \mathrm{L}$ 의 부탄 올이 되었으며 이로써 시약급 유기산 이용 시와 차이가 없 음으로 판단된다.

음식물쓰레기의 혐기성소화 공정에서 발생되는 산발효액 이 부탄올 생산의 원료로 활용될 수 있음을 본 연구에서 확 인하였다. 산발효액 유래의 부탄올 생산은 기존의 바이오가 스만을 생산하던 혐기성소화 공정 외에 알코올을 추가적으 로 생산하여 활용처를 확대할 수 있는 기술로 사료된다.

\section{Acknowledgement}

본 연구는 산업통상자원부(MOTIE)와 한국에너지기술평가 원(KETEP)의 지원을 받아 수행한 연구 과제입니다(No. 20163010092150).

KSEE

\section{References}

1. Roberto, da S. W. and DosSantos, R. G., "Review on the characteristics of butanol, its production and use as fuel in internal combustion engines," Renew. and Sust. Energy Rev., 69, 642 651(2017).

2. Edwards, R., L., J.-F. and Beziat, J-C., Well-to-wheels Analysis of Future Automotive Fuels and Powertrains in the European Context Joint Research Centre of the European Commission, EUCAR and CONCAWE Report Version 2a(2011).

3. Ndaba, B., Chiyanzu, I. and Marx, S., "n-Butanol derived from biochemical and chemical routes: A review," Biotechnol. Reports, 8 (Supplement C), 1 9(2015).

4. Cao, G., Sheng, Y., Zhang, L., Song, J., Cong, H. and Zhang, J., "Biobutanol Production from Lignocellulosic Biomass: Prospective and Challenges," J. Bioremediat. \& Biodegrad., 7(4), (2016).

5. Bowles, L. K. and Ellefson, W. L., "Effects of butanol on Clostridium acetobutylicum," Appl. and Environ. Microbiol., 50(5), 1165 1170(1985).

6. Outram, V., Lalander, C.-A., Lee, J. G. M., Davies, E. T. and Harvey, A., "Applied in situ product recovery in ABE fermentation," Biotechnol. Prog., 33(3), 563 579(2017).

7. Patakova, P., Maxa, D., Rychtera, M., Linhova, M., Fribert, P., Muzikova, Z., Lipovsky, J., Paulova, L., Pospisil, M., Sebor, G. and Melzoch, K., Perspectives of Biobutanol Production and Use. In: Bernardes, M.A.d.S. (ed.) Biofuel's Eng. Proc. Technol., 11, InTech, Rijeka(2011).

8. Lee, J. C., Kim, J. H., Park, H. S. and Pak, D. W., "Bioethanol production using batch reactor from foodwastes," $J$. Korean Soc. Environ. Eng., 32(6), 609 614(2010).

9. Girotto, F., Alibardi, L. and Cossu, R., "Food waste generation and industrial uses: A review," Waste Manage., 45 (Supplement C), 32 41(2015). 
10. Kumar, G., Sivagurunathan, P., Park, J.-H. and Kim, S.-H., "Anaerobic digestion of food waste to methane at various organic loading rates (OLRs) and hydraulic retention times (HRTs): Thermophilic vs. mesophilic regimes," Environ. Eng. Res., 21(1), 69 73(2016).

11. Achinas, S., Achinas, V. and Euverink, G. J. W., "A Technological Overview of Biogas Production from Biowaste," Engineering, 3, 299 307(2017).

12. Yasin, N. H. M., Mumtaz, T., Hassan, M. A. and Abd Rahman, N. A., "Food waste and food processing waste for biohydrogen production," A Rev. J. Environ. Manage., 130 (Supplement C), 375 385(2013).

13. Shinto, H., Tashiro, Y., Yamashita, M., Kobayashi, G., Sekiguchi, T., Hanai, T., Kuriya, Y., Okamoto, M. and Sonomoto, K., "Kinetic modeling and sensitivity analysis of acetonebutanol-ethanol production," J. Biotechnol., 131(1), 45 56 (2007).

14. Formanek, J., Mackie, R. and Blaschek, H. P., "Enhanced Butanol Production by Clostridium beijerinckii BA101 Grown in Semidefined P2 Medium Containing 6 Percent Maltodextrin or Glucose," Appl. Environ. Microbiol., 63(6), 2306 2310
(1997).

15. Sandoval-Espinola, W. J., Jose, M. C. and Bruno-Barcena, M., "Inoculum optimization of Clostridium beijerinckii for reproducible growth," FEMS Microbiol. Lett., 362(19), (2015).

16. Chmiel, M. T. and Yargeau, V., "Biohydrogen production by Clostridium beijerinckii," WIT Press, 84, (2015).

17. Yu, M., Zhang, Y., Tang, I. C., Yang, S.-T., "Metabolic engineering of Clostridium tyrobutyricum for n-butanol production," Metabolic Eng., 13(4), 373 382(2011).

18. Al-Shorgani, N. K. N., Ali, E., Kalil, M. S. and Yusoff, W. M. W., "Bioconversion of Butyric Acid to Butanol by Clostridium saccharoperbutylacetonicum N1-4 (ATCC 13564) in a Limited Nutrient Medium," Bioenerg. Res., 5, 287 293 (2012).

19. Gottschal, J. C. and Morris, J. G., "The induction of acetone and butanol production in cultures of Clostridium acetobutylicum by elevated concentrations of acetate and butyrate" FEMS Microbiol. Lett., 12(4), 385 389(1981).

20. Lu, C., Dong, J. and Yang, S.-T., "Butanol production from wood pulping hydrolysate in an integrated fermentation-gas stripping process," Bioresour. Technol., 143, 467 475(2013). 